\title{
Spineless cactus as a replacement for wheat bran in sugar cane-based diets for sheep: intake, digestibility, and ruminal parameters
}

\author{
Stephany Emyle Barbosa Lins ${ }^{1}$, Ricardo Alexandre Silva Pessoa ${ }^{2}$, Marcelo de Andrade \\ Ferreira², José Maurício de Souza Campos ${ }^{3}$, José Augusto Bastos Afonso da Silva ${ }^{4}$, Janaina \\ de Lima Silva ${ }^{2}$, Stefanie Alvarenga Santos ${ }^{5}$, Tobias Tobit de Barros Melo
}

\author{
${ }^{1}$ Universidade Federal Rural de Pernambuco, Programa de Pós-graduação em Ciência Animal e Pastagens, Garanhuns, PE, Brasil \\ ${ }^{2}$ Universidade Federal Rural de Pernambuco, Departamento de Zootecnia, Recife, PE, Brasil. \\ ${ }^{3}$ Universidade Federal de Viçosa, Departamento de Zootecnia, Viçosa, MG, Brasil. \\ ${ }^{4}$ Universidade Federal Rural de Pernambuco, Clínica de Bovinos, Garanhuns, PE, Brasil. \\ ${ }^{5}$ Universidade Federal da Bahia, Escola de Medicina Veterinária e Zootecnia, Salvador, BA, Brasil.
}

ABSTRACT - The objective of this study was to evaluate the effect of replacing wheat bran by spineless cactus $(0,25,50$, 75 , and $100 \%$ ) in sugar cane-based diets on intake and nutrient digestibility and ruminal parameters of sheep. Five sheep (Santa Inês; average initial weight of $34.0 \pm 3.6 \mathrm{~kg}$ ) were fitted with cannulas in the rumen and then assigned to a $5 \times 5$ Latin square design. The maximum dry matter (DM; $\left.1414 \mathrm{~g} \mathrm{~d}^{-1}\right)$, digestible organic matter $\left(658 \mathrm{~g} \mathrm{~d}^{-1}\right)$, and neutral detergent fiber corrected for ash and protein (NDFap; $425 \mathrm{~g} \mathrm{~d}^{-1}$ ) intakes were estimated by replacing 80.2, 89.9, and 50.5\% of wheat bran. Dry matter and crude protein digestibility increased by 0.60 and $0.85 \mathrm{~g} \mathrm{~kg}^{-1}$ of DM. With the replacement of 57.1 and $62.2 \%$ of wheat bran, a maximum rate of NDF ingestion $\left(0.70 \mathrm{~h}^{-1}\right)$ and NDF ruminal pool $(7.31 \mathrm{~g})$ was obtained. Rumen $\mathrm{pH}$ increased with the inclusion of spineless cactus, while the maximum concentration of ammonia $\mathrm{N}(33.3 \mathrm{mg} \mathrm{dL}-1)$ and total volatile fatty acids $\left(57.7 \mu \mathrm{mol} \mathrm{mL} \mathrm{m}^{-1}\right)$ were estimated at the levels of 72.3 and $63.7 \%$ of replacement of wheat bran. It is recommended to replace $63 \%$ of wheat bran by spineless cactus in sugar cane-based diets, to promote better animal performance.

Key Words: animal nutrition, cactaceous, dry season, feed intake, rumen fermentation, semiarid

\section{Introduction}

In arid regions, small ruminants are the main producing species of meat and milk, not only for subsistence but also for the consumer market. Because of the high cost of production, farmers use little technology and feedstock, a fact that is aggravated by environmental conditions, such as severe droughts (Ben Salem and Smith, 2008). Another fact that suggests considerable concern among producers of milk and meat is the increased use of concentrate to maintain production in the dry season.

The ingredients that traditionally make up concentrate feed are difficult to produce in semiarid regions due to the rainfall irregularity. Thus, the replacement of wheat bran, a widely used ingredient in feed formulation (Melaku et al., 2005; Monteiro et al., 2014; Touno et al., 2014), could reduce production costs and make the animal production more sustainable.

Received August 4, 2015 and accepted October 26, 2015. Corresponding author: silva_janainalima@yahoo.com.br

http://dx.doi.org/10.1590/S1806-92902016000100004

Copyright (C) 2016 Sociedade Brasileira de Zootecnia. This is an Open Access article distributed under the terms of the Creative Commons Attribution License (http://creativecommons.org/licenses/by/4.0/), which permits unrestricted use, distribution, and reproduction in any medium, provided the original work is properly cited.
The replacement of the concentrate or part thereof by spineless cactus could reduce feed costs. Currently, the spineless cactus has a cost to the producer of US\$0.10, compared with the of US\$0.17 of wheat bran, justifying the use of the cactus. However, the spineless cactus has a low neutral detergent fiber content $\left(170-280 \mathrm{~g} \mathrm{~kg}^{-1} \mathrm{DM}\right)$ (Ferreira et al., 2011), which suggests an association with forage containing effective fiber.

Among the available forages, sugar cane is traditionally used in Brazil because its production coincides with the period of forage scarcity (Mariz et al., 2013). The use of spineless cactus associated with sugar cane is scarce and justifies more studies. There is a hypothesis that the high concentration of non-fiber carbohydrates (640-710 $\mathrm{g} \mathrm{kg}^{-1}$ DM) of spineless cactus with rapid degradation could allow the use of a higher amount of urea for protein correction (Ferreira et al., 2011). It also could allow a better use of the potentially digestible fiber from sugar cane.

In studies with beef cattle, Valadares Filho et al. (2014) found an urea content of up to $1.0 \%$ in the total dry matter of the diet, but higher levels of urea could be used, providing satisfactory performance. For sheep, a maximum level of urea inclusion that could adversely affect the performance of sheep has not been suggested. 
In the literature, the urea content has been found to range from $1.5 \%$ (Alves et al., 2012) to $2.4 \%$ (Vidal et al., 2004) in the total dry matter of sheep diet, without compromising intake or performance.

Thus, we hypothesized that spineless cactus, high in non-fiber carbohydrates, could replace partially or totally wheat bran in sugar cane-based diets, evaluating the effects on intake and nutrient digestibility and ruminal parameters in sheep.

\section{Material and Methods}

The experiment was conducted in Recife - PE, Brazil.

The management and care of animals were performed according to the guidelines and recommendations of the Committee of Ethics on Animal Use (CEUA) of Universidade Federal Rural de Pernambuco. Five uncastrated male sheep of the Santa Inês breed with an average initial body weight of $34.0 \pm 3.6 \mathrm{~kg}$ and fitted with cannulas in the rumen were assigned to a $5 \times 5$ latin square design, with five treatments and five experimental periods. The animals were kept in indoor facilities with individual stalls provided with a feeder and drinker.

Experimental diets (Table 1) consisted of the replacement of wheat bran by spineless cactus (Nopalea cochenillifera Salm-Dyck) in the proportions of 0, 25, 50, 75 , and $100 \%$ (Table 2). The diets were supplied ad libitum, as a complete ration, twice daily, at 08.00 and $16.00 \mathrm{~h}$ and adjusted daily, formulated to provide $13 \%$ as orts. The sugar cane (Saccharum officinarum L.) was corrected with urea and ammonium sulfate.

Each experimental period (five periods) lasted 15 days, with the first eight days dedicated to animal adaptation (Storry and Sutton, 1969; Menezes et al., 2011). Voluntary intake was evaluated from the 4th to 11th day of each experimental period with samples of ingredients, orts, and feces (total collection used a collection bag attached to the

Table 1 - Chemical composition of ingredients on a dry matter basis

\begin{tabular}{|c|c|c|c|c|}
\hline & $\begin{array}{l}\text { Sugar } \\
\text { cane }\end{array}$ & Corn & $\begin{array}{l}\text { Wheat } \\
\text { bran }\end{array}$ & $\begin{array}{c}\text { Spineless } \\
\text { cactus }\end{array}$ \\
\hline Dry matter ${ }^{1}$ & 275 & 888 & 908 & 99.1 \\
\hline Organic matter ${ }^{2}$ & 968 & 983 & 891 & 851 \\
\hline Crude protein ${ }^{2}$ & 24.0 & 88.7 & 159 & 51.0 \\
\hline Ether extract ${ }^{2}$ & 9.10 & 46.0 & 50.3 & 13.5 \\
\hline $\mathrm{NDFap}^{2}$ & 440 & 190 & 434 & 232 \\
\hline Non-fiber carbohydrates ${ }^{2}$ & 495 & 658 & 247 & 555 \\
\hline
\end{tabular}

animals) collected for the three consecutive days of each period.

Rumen fluid was collected from the 11th to 13th day of each experimental period, before feeding and two, four, and six hours after feeding. The manual collection was performed at several locations in the ruminal environment, taking a representative sample of the content $(100 \mathrm{~mL})$, which was filtered through cotton fabric. After collection, $\mathrm{pH}$ was measured with a digital potentiometer. The ammonia nitrogen $\left(\mathrm{N}-\mathrm{NH}_{3}\right)$ concentration was determined after samples were centrifuged at 3,000 rpm/15 min, using the supernatant for analysis by Kjeldahl distillation (Detmann and Valadares Filho, 2010). Aliquots for the assessment of the main volatile fatty acids (acetate, propionate, and butyrate) were defrosted and centrifuged at $15,000 \times \mathrm{g}$, at $4{ }^{\circ} \mathrm{C}$ for $60 \mathrm{~min}$. Analysis of volatile fatty acids (VFA) was performed using a gas chromatograph equipped with a flame ionization detector and auto-injector and coupled to a GP column $(30 \mathrm{~m} \times 0.250 \mathrm{~mm}, 0.25 \mu \mathrm{m}$; Chromosorb WAW).

On day 13 , the rumen was completely emptied four hours after the morning diet was provided to determine the rates of indigestion and ruminal pool for each diet using the technique described by Allen and Linton (2007). On day 15, the rumen was emptied immediately before the morning feeding. After emptying the rumen, the total weight of the digesta was determined, followed by filtering through four layers of cheesecloth to separate the solid and liquid phases. A representative sample of both phases was collected and

Table 2 - Proportion of ingredients and chemical composition of the diet

\begin{tabular}{|c|c|c|c|c|c|}
\hline & \multicolumn{5}{|c|}{ Replacement level (\%) } \\
\hline & 0 & 25 & 50 & 75 & 100 \\
\hline \multicolumn{6}{|l|}{ Ingredient $^{1}$} \\
\hline Sugar cane & 369 & 369 & 373 & 375 & 377 \\
\hline Corn & 79.3 & 79.9 & 80.6 & 80.8 & 80.8 \\
\hline Wheat bran & 529 & 396 & 262 & 127 & 0 \\
\hline Spineless cactus & 0 & 125 & 249 & 375 & 492 \\
\hline Urea/ammonium sulfate & 13.4 & 19.3 & 26.3 & 32.4 & 39.4 \\
\hline Mineral & 7.28 & 7.33 & 7.38 & 7.41 & 7.40 \\
\hline Sodium chloride & 2.36 & 2.41 & 2.46 & 2.46 & 2.49 \\
\hline \multicolumn{6}{|l|}{ Chemical composition } \\
\hline Dry matter ${ }^{2}$ & 490 & 314 & 232 & 184 & 154 \\
\hline Organic matter ${ }^{1}$ & 943 & 932 & 923 & 913 & 903 \\
\hline Crude protein ${ }^{1}$ & 136 & 137 & 140 & 141 & 146 \\
\hline Ether extract ${ }^{1}$ & 30.4 & 26.3 & 22.1 & 17.8 & 13.8 \\
\hline NDFap $^{1}$ & 407 & 379 & 351 & 323 & 296 \\
\hline $\mathrm{iNDF}^{1}$ & 160 & 189 & 201 & 199 & 180 \\
\hline Non-fiber carbohydrates ${ }^{1}$ & 392 & 422 & 453 & 484 & 513 \\
\hline
\end{tabular}


frozen $\left(-20^{\circ} \mathrm{C}\right)$ for later evaluation of dry matter (DM), neutral detergent fiber (NDF), and indigestible neutral detergent fiber (iNDF) contents. After sampling, the phases were again mixed, and the remaining digesta was returned to the rumen.

At the end of each period, a composite sample was prepared from the leftovers, feces, and ruminal digesta based on the air-dried weight of the samples for each animal, and the samples were then properly identified and stored in plastic containers for further analysis. At the end of the sampling period, the ingredients of diets, orts, fecal samples, and ruminal content samples were oven-dried $\left(60{ }^{\circ} \mathrm{C}\right)$ and ground.

Dry matter, organic matter $(\mathrm{OM})$, and crude protein (CP) analyses were performed according to the AOAC (1990), method number 934.01 for DM, 930.05 for OM, and 981.10 for CP. Ether extract (EE) was analyzed by Soxhlet extraction with petroleum ether, according to the AOAC (1990), method number 920.39. The concentration of NDF was assayed with heat-stable amylase and corrected for ash and nitrogen compounds [aNDFom(n)] by using techniques described by Mertens (2002), with corrections for protein according to Licitra et al. (1996) and thermostable alpha-amylase added. Neutral detergent insoluble nitrogen (NDIN) and acid detergent insoluble nitrogen (ADIN) (Licitra et al., 1996) were measured using the Kjeldahl method. Non-fiber carbohydrates (NFC) were calculated according to Hall (2000), as follows:

$\mathrm{NFC}\left(\mathrm{g} \mathrm{kg}^{-1}\right)=1000-[(\mathrm{CP}-$ urea-derived CP + urea $)+$ $\mathrm{NDFap}+\mathrm{EE}+\mathrm{ash}]$,

in which $\mathrm{CP}=$ crude protein; $\mathrm{NDFap}=$ neutral detergent fiber corrected for ash and protein; and $\mathrm{EE}=$ ether extract.

The experiment was analyzed as a $5 \times 5$ Latin square design using the MIXED procedure of SAS (Statistical Analysis System, version 9.4), according to the following model:

$$
\mathrm{Y}_{\mathrm{ijk}}=\mu+D_{\mathrm{i}}+a_{\mathrm{j}}+p_{\mathrm{k}}+\varepsilon_{\mathrm{ijk}},
$$

in which $\mu$ is the overall constant; $D_{\mathrm{i}}$ is the fixed effect of diet $\mathrm{I} ; a_{\mathrm{j}}$ is the random effect of animal $\mathrm{j} ; p_{\mathrm{k}}$ is the random effect of experimental period $\mathrm{k}$; and $\varepsilon_{\mathrm{ijk}}$ is the random unobservable error.

After analysis of variance, the significance of the linear and quadratic effects of the replacement of the total of wheat bran in the basal diet by spineless cactus was evaluated. A significance value of 0.05 was adopted as the critical value of the probability of type-I error. Rumen $\mathrm{pH}$, ammonia nitrogen $\left(\mathrm{NH}_{3}-\mathrm{N}\right)$, and volatile fatty acids (VFA) were considered the effect of sampling time as repeated measures in time.

\section{Results}

A quadratic effect $(\mathrm{P}<0.05)$ was found on the intakes of DM and nutrients (Table 3). The intakes of DM (1414 $\left.\mathrm{g} \mathrm{d}^{-1}\right)$, OM (1281 $\mathrm{g} \mathrm{d}^{-1}$ ), CP (204 $\left.\mathrm{g} \mathrm{d}^{-1}\right)$, NDFap (425 $\left.\mathrm{g} \mathrm{d}^{-1}\right)$, NFC $\left(657 \mathrm{~g} \mathrm{~d}^{-1}\right)$, and digestible OM (658 $\left.\mathrm{g} \mathrm{d}^{-1}\right)$ were achieved at the levels of $80.2,75.3,88.6,50.5,89.9$ and $89.9 \%$ of replacement of wheat bran respectively. However, the digestibility of DM and $\mathrm{CP}$ had a linear effect $(\mathrm{P}<0.05)$ (Table 3$)$. The experimental diets had no effect $(\mathrm{P}>0.05)$ on the apparent digestibility of OM, NDF, and NFC.

Similarly to DM intake, a quadratic effect $(\mathrm{P}<0.05)$ was found for rate of ingestion of NDF, with maximum point $\left(0.70 \mathrm{~h}^{-1}\right)$ estimated at $57.1 \%$ of replacement of the wheat bran (Table 3). Conversely, the minimum ruminal pool $(\mathrm{P}<0.05)$ of NDF $(7.31 \mathrm{~g})$ was achieved with $62.2 \%$ of replacement of wheat bran (Table 3$)$. No effect $(\mathrm{P}>0.05)$ was found for the ruminal pool of iNDF.

The experimental diets had an effect on the ruminal parameters (Table 4). The rumen $\mathrm{pH}$ increased linearly $(\mathrm{P}<0.05)$ as the spineless cactus increased, but conversely reduced $(\mathrm{P}<0.05)$ with respect to collection time. Conversely, a quadratic effect $(\mathrm{P}<0.05)$ was found for ammonia $\mathrm{N}\left(\mathrm{N}-\mathrm{NH}_{3}\right)$, compared with the diets $\left(33.3 \mathrm{mg} \mathrm{dL}^{-1}\right.$ achieved with $72.3 \%$ of wheat bran replacement) and ruminal collection time (42.8 $\mathrm{mg} \mathrm{dL}^{-1}$ achieved three hours after feeding). Similarly, a quadratic effect $(\mathrm{P}<0.05)$ was found for short-chain fatty acids (SCFA), concentrations of acetate, propionate and butyrate, and acetate/propionate $(\mathrm{A} / \mathrm{P})$ ratio. The maximum point was found with $57.7 \mu \mathrm{mol} \mathrm{mL} \mathrm{mL}^{-1}$ of SCFA, $34.5 \mu \mathrm{mol} \mathrm{mL} \mathrm{m}^{-1}$ of acetate, $15.3 \mu \mathrm{mol} \mathrm{mL} \mathrm{mL}^{-1}$ of propionate, $7.66 \mu \mathrm{mol} \mathrm{mL}^{-1}$ of butyrate, and an $\mathrm{A} / \mathrm{P}$ ratio of 2.16 , with replacement levels of $63.7,70.6,54.2,57.5$, and $46.5 \%$ (Table 4 ).

\section{Discussion}

The replacement of wheat bran by spineless cactus provided a higher nutrient intake, explained by the increase in the concentration of easily fermentable carbohydrates (NFC) and the lower iNDF content of the diets, promoting better dry matter digestibility (Table 3). The spineless cactus can be considered a good source of fermentable carbohydrates of rapid degradation (Batista et al., 2009), improving digesta flow through the gastrointestinal tract with a consequent increase in intake.

The non-fiber carbohydrate contents of the diets (Table 2) were above $30 \%$, which, according, to Hoover (1986) is sufficient to reduce intake. However, in this study, the DM intake increased until $80 \%$ replacement of wheat bran. The inclusion of spineless cactus allowed for the balancing of 
the ruminal environment, evidenced by the average rumen $\mathrm{pH}$ of 6.8 (Table 4), which remained at adequate levels (6.2 to 7.0), according to Hoover (1986), with the aid of the effective fiber presence (sugar cane). The $\mathrm{pH}$ values for all replacement levels were close to the acceptable range for microbial growth and ruminal fiber digestion. According to Abidi et al. (2009), the mucilage in spineless cactus cladodes may stimulate salivation, thus preventing $\mathrm{pH}$ decrease.
A possible hypothesis for the quadratic effect of nutrient intake is the excess of rapidly degradable nitrogen in the rumen (urea), which not only affects the palatability of the diet but also compromises ruminal fermentation. Another hypothesis is the high moisture content in the spineless cactus causing rumen filling (Gebremarian et al., 2006). In the present study, a DM content of spineless cactus of $99.1 \mathrm{~g} \mathrm{~kg}^{-1}$ was found (Table 1), and, according to Minson

Table 3 - Intake and digestibility of nutrients, rate of ingestion (ki) of NDF, and pool sizes of the diet components in sheep fed diets containing different levels of replacement of wheat bran with spineless cactus

\begin{tabular}{|c|c|c|c|c|c|c|c|}
\hline \multirow{2}{*}{ Item } & \multicolumn{5}{|c|}{ Replacement level (\%) } & \multirow{2}{*}{ SEM } & \multirow{2}{*}{ P-value } \\
\hline & 0 & 25 & 50 & 75 & 100 & & \\
\hline \multicolumn{8}{|l|}{ Intake $\left(\mathrm{g} \mathrm{d}^{-1}\right)$} \\
\hline Dry matter ${ }^{1}$ & 949 & 1170 & 1348 & 1426 & 1376 & 88.5 & 0.014 \\
\hline Organic matter $^{2}$ & 896 & 1091 & 1243 & 1303 & 1246 & 73.9 & 0.013 \\
\hline Crude protein ${ }^{3}$ & 124 & 158 & 190 & 204 & 202 & 15.3 & 0.009 \\
\hline $\mathrm{NDFap}^{4}$ & 380 & 406 & 429 & 415 & 377 & 10.1 & 0.046 \\
\hline Non-fiber carbohydrates ${ }^{5}$ & 363 & 497 & 595 & 658 & 649 & 55.3 & 0.009 \\
\hline \multicolumn{8}{|l|}{ Digestibility $\left(\mathrm{g} \mathrm{kg}^{-1}\right)$} \\
\hline Dry matter ${ }^{7}$ & 687 & 680 & 740 & 724 & 740 & 12.9 & 0.028 \\
\hline Organic matter & 708 & 701 & 760 & 751 & 766 & 13.6 & 0.128 \\
\hline Crude protein ${ }^{8}$ & 794 & 803 & 848 & 854 & 875 & 15.5 & 0.001 \\
\hline Neutral detergent fiber & 538 & 500 & 567 & 538 & 557 & 11.5 & 0.959 \\
\hline Non fibrous carbohydrates & 927 & 931 & 954 & 946 & 941 & 4.91 & 0.170 \\
\hline
\end{tabular}

SEM - standard error of the mean; NDFap - neutral detergent fiber corrected for ash and protein; iNDF - indigestible neutral detergent fiber; NDF - neutral detergent fiber; $\mathrm{P}$-value - significance level $(\alpha=0.05)$.

${ }^{1} \hat{Y}=940.34+11,78 X-0.0734 X^{2}$.

${ }^{2} \hat{Y}=887.89+10.449 X-0.0694 X^{2}$.

${ }^{3} \hat{Y}=121.84+1.85 X-0.01044 X^{2}$.

${ }^{4} \hat{Y}=376.98+1.90 \mathrm{X}-0.0188 \mathrm{X}^{2}$.

${ }^{5} \hat{Y}=359.94+6.6006 X-0.0367 X^{2}$

${ }^{6} \hat{Y}=616.46+8.9434 X-0.0545 X^{2}$

${ }^{7} \hat{Y}=683.78+0.6039 X$.

${ }^{8} \hat{Y}=792.47+0.8453 X$

${ }^{9} \hat{Y}=0.04739+0.0008136 \mathrm{X}-0.00000713 \mathrm{X}^{2}$.

${ }^{10} \hat{Y}=9.9111-0.0834 X+0.0006709 X^{2}$

Table 4 - Ruminal parameters of sheep fed diets containing different levels of replacement of wheat bran with spineless cactus

\begin{tabular}{|c|c|c|c|c|c|c|c|c|c|c|}
\hline \multirow{2}{*}{ Item } & \multicolumn{5}{|c|}{ Replacement level (\%) } & \multirow{2}{*}{ SEM } & \multicolumn{2}{|c|}{ Diet effect } & \multicolumn{2}{|c|}{ Time effect } \\
\hline & 0 & 25 & 50 & 75 & 100 & & $\mathrm{~L}$ & Q & $\mathrm{L}$ & Q \\
\hline $\mathrm{pH}^{1}$ & 6.61 & 6.68 & 6.71 & 6.89 & 6.91 & 0.10 & 0.001 & 0.877 & $<0.001$ & $<0.001$ \\
\hline $\mathrm{N}-\mathrm{NH}_{3}\left(\mathrm{mg} \mathrm{dL}^{-1}\right)^{2}$ & 24.5 & 27.7 & 32.9 & 33.9 & 31.2 & 1.76 & 0.009 & 0.018 & 0.135 & $<0.001$ \\
\hline \multicolumn{11}{|c|}{ Volatile fatty acid $\left(\mathrm{mmol} \mathrm{L}^{-1}\right)$} \\
\hline Total $^{3}$ & 38.9 & 56.9 & 56.4 & 52.7 & 54.9 & 1.88 & 0.007 & 0.005 & $<0.001$ & $<0.001$ \\
\hline Acetate $^{4}$ & 24.1 & 33.6 & 33.6 & 32.2 & 34.7 & 1.79 & 0.006 & 0.033 & 0.005 & $<0.001$ \\
\hline Propionate $^{5}$ & 10.1 & 15.6 & 15.8 & 12.8 & 13.6 & 0.95 & 0.174 & 0.002 & $<0.001$ & $<0.001$ \\
\hline Butyrate $^{6}$ & 4.69 & 7.75 & 6.96 & 7.71 & 6.68 & 0.57 & 0.031 & 0.005 & 0.088 & $<0.001$ \\
\hline Acetate/propionate ratio ${ }^{7}$ & 2.41 & 2.18 & 2.14 & 2.5 & 2.60 & 0.10 & 0.169 & 0.044 & $<0.001$ & $<0.001$ \\
\hline
\end{tabular}

$\mathrm{SEM}$ - standard error of the mean; $\mathrm{N}_{-} \mathrm{NH}_{3}$ - ammonia nitrogen; L - linear effect; Q - quadratic effect.

${ }^{1} \hat{Y}=6.594+0.0034 X$.

${ }^{2} \hat{\mathrm{Y}}=23.861+0.2601 \mathrm{X}-0.0018 \mathrm{X}^{2}$.

${ }^{3} \hat{Y}=41.464+0.5087 \mathrm{X}-0.004 \mathrm{X}^{2}$.

${ }^{4} \hat{Y}=26.635+5.1004 X-0.7353 X^{2}$.

${ }^{5} \hat{Y}=9.4814+4.1062 X-0.5873 X^{2}$.

${ }^{6} \hat{Y}=5.8054+1.105 \mathrm{X}-0.1688 \mathrm{X}^{2}$

${ }^{7} \hat{Y}=2.3774-0.0093 \mathrm{X}+0.0001 \mathrm{X}^{2}$. 
(1990), water contents in forages exceeding $780 \mathrm{~g} \mathrm{~kg}^{-1}$ can compromise voluntary intake.

The presence of minor NDFap amounts in the diets explains the reduction of the intake of this nutrient after the level of $50 \%$ wheat bran replacement, as well as the presence of increasing amounts of NFC. However, approximately $31 \%$ of NDFap in the diet favored the maximum DM intake. For lactating cows, the NRC (2001) recommends a maximum of $44 \%$ of NFC in DM, and at least $25 \%$ of NDF, with an effective fiber source. From this result, it can be inferred that sheep are more tolerant to higher NFC levels than cattle, which may be related to the eating habits of the animals.

The increase in non-protein nitrogen (NPN) in the diets explains the higher digestibility of crude protein, since it is completely solubilized in the rumen and rapidly converted to ammonia by bacteria attached to the ruminal wall (Eustaquio Filho et al., 2008). Although soluble nitrogen in the ruminal environment can increase NDF digestibility (Detmann et al., 2008), this effect was not observed for this nutrient (Table 3).

The replacement of a fibrous feedstuff like wheat bran $(43.4 \% \mathrm{NDF})$ by the spineless cactus $(23.2 \% \mathrm{NDF})$ explains the increase in ingestion rate of NDF ( $k$ i) up to $50 \%$ of replacment of wheat bran. The effect of wheat bran on the intake rate can be observed by the higher presence of NDF resident mass in the rumen (NDF ruminal pool) of the control diet (100\% wheat bran). The increased nutrient intake and the reduction in fiber ruminal retention time in the presence of the spineless cactus corroborate Huhtanen et al. (1995), who reported inverse relations between DM intake and retention time.

Melaku et al. (2005) found fewer particles flowing through the rumen and a higher fiber total retention time in sheep fed wheat bran. Therefore, it is important to note that the use of spineless cactus provided a higher particle flow in the rumen, with less NDF retention $(7.31 \mathrm{~g})$ with the replacement of $62.2 \%$ of wheat bran (Table 3 ).

The estimated concentration of ammonia-N $\left(33.3 \mathrm{mg} \mathrm{dL}^{-1}\right)$ was achieved with $72.3 \%$ replacement of wheat bran. According to Leng (1990), the minimum amount of ammonia $\mathrm{N}$ necessary for maximum microbial growth ranges from 10 to $20 \mathrm{mg} \mathrm{dL}^{-1}$. The increase in the intake of digestible organic matter (Table 3) and NPN derived from urea probably resulted in higher concentrations of ammonia N, which, according to Van Soest (1982), creates a suitable ruminal environment for cellulolytic microorganisms to ferment fiber effectively. In this study, there was no effect on the digestibility of fiber, probably because the replacement of the NPN amount at all levels (with a minimum concentration of $24.5 \mathrm{mg} \mathrm{dL}^{-1}$ at $0 \%$ of replacement) was sufficient to allow for fiber digestion.

The peak production of rumen $\mathrm{NH}_{3}-\mathrm{N}\left(42.8 \mathrm{mg} \mathrm{dL}^{-1}\right)$ occurred three hours after feeding, probably due to the presence of low rumen-degradability fiber originating from sugar cane. Also, because of the presence of wheat bran, microbial fermentation became slower, as evidenced by the increased retention of food (Table 3), thus delaying the ammonia-N peak.

When there is a predominance of fibrous carbohydrates in diets, ruminal microorganisms direct the production of short-chain fatty acids (SCFA) to acetate production. However, a higher concentration of acetate was observed at the higher wheat bran replacement levels (Table 4), indicating that soluble carbohydrates and pectin in the spineless cactus were preferably fermented. When soluble carbohydrates are abundant, bacteria produce both acetate and ethanol as formate, and, if the rapidly fermentable substrate is reduced, the final products are acetate and propionate (Antunes et al., 2011).

The high degradability of spineless cactus has become known for maximizing the rumen fermentation capacity and increasing microbial protein synthesis, SCFA production and, consequently, nutrient conduction for animals (Ferreira et al., 2009). It was found that maximum production of total SCFA $\left(57.7 \mu \mathrm{mol} \mathrm{mL} \mathrm{m}^{-1}\right.$, Table 4$)$ was obtained with $63.7 \%$ replacement of wheat bran by spineless cactus.

\section{Conclusions}

The spineless cactus has proven to be a food alternative in semi-arid regions, replacing up to $80 \%$ of wheat bran in sheep diet without affecting dry matter intake. To promote better animal performance, it is recommended to replace $63 \%$ of wheat bran by spineless cactus in sugar cane-based diets because of the optimal ruminal fermentation and higher volatile fatty acids synthesis for the animal.

\section{Acknowledgments}

This work was supported by Conselho Nacional de Desenvolvimento Científico e Tecnológico - CNPq.

\section{References}

Abidi, S.; Ben Salem, H.; Vasta, V. and Priolo A. 2009. Supplementation with barley or spineless cactus (Opuntia ficus indica $\mathrm{f}$. inermis) cladodes on digestion, growth and intramuscular fatty acid composition in sheep and goats receiving oaten hay. Small Ruminant Research 87:9-16. 
Antunes, R. C.; Rodriguez, N. M. and Saliba, E. O. S. 2011. Metabolismo dos carboidratos não estruturais. p.239-263. In: Nutrição de ruminantes. 2.ed. Berchielli, T. T.; Pires, A. V and Oliveira, S. G., eds. Funep, Jaboticabal.

Allen, M. S. and Linton, J. A. V. 2007. In vivo methods to measure digestibility and digestion kinetics of feed fractions in the rumen. p.72-89. In: Anais do Simpósio Internacional Avanços em Técnicas de Pesquisa em Nutrição de Ruminantes. USP, Pirassununga.

Alves, E. M.; Pedreira, M. S.; Pereira, M. L. A.; Almeida, P. J. P.; Gonsalves Neto, J. and Freire, L. D. R. 2012. Farelo de vagem de algaroba associado a níveis de ureia na alimentação de ovinos: balanço de nitrogênio, $\mathrm{N}$-ureico no plasma e parâmetros ruminais. Acta Scientiarum. Animal Sciences 34:287-295.

AOAC - Association of Official Analytical Chemists. 1990. Official methods of Analysis. 15th ed. AOAC International, Arlington, VA.

Batista, A. M. V.; Ribeironeto, A. G.; Lucena, R. B.; Santos, D. C.; Dubeux Jr., J. B. and Mustafa, A. F. 2009. Chemical composition and ruminal degradability of spineless cactus grown in Northeastern Brazil. Rangeland Ecology \& Management 62:297-301.

Ben Salem, H. and Smith, T. 2008. Feeding strategies to increase small ruminant production in dry environments. Small Ruminant Research 77:174-194.

Detmann, E.; Paulino, M. F. and Valadares Filho, S. C. 2008. Avaliação nutricional de alimentos ou de dietas? Uma abordagem conceitual. p.21-51. In: Anais do 6o Simpósio Internacional de Produção de Gado de Corte. Universidade Federal de Viçosa, Viçosa, MG.

Detmann, E. and Valadares Filho, S. C. 2010. On the estimation of non-fibrous carbohydrates in feeds and diets. Arquivos Brasileiros de Medicina Veterinária e Zootecnia 62:980-984.

Eustaquio Filho, A.; Santos, P. E. F. and Yamamoto S. M. 2008. Utilização de ureia como fonte de nitrogênio não proteico (NNP) para ruminantes. Pubvet 2:32.

Ferreira, M. A.; Silva, F. M.; Bispo, S. V. and Azevedo M. 2009. Estratégias na suplementação de vacas leiteiras no semi-árido do Brasil. Revista Brasileira de Zootecnia 38:322-329.

Ferreira, M. A.; Pessoa, R. A. S.; Silva, F. M. and Bispo, S. V. 2011. Palma forrageira e ureia na alimentação de vacas leiteiras. Editora UFRPE, Recife.

Gebremarian, T.; Melaku, S. and Yami, A. 2006. Effect of different levels of cactus (Opuntia ficus-indica) inclusion on feed intake, digestibility and body weight gain in tef (Eragrostis tef) strawbased feeding of sheep. Animal Feed Science and Technology 131:42-51.

Hall, M. B. 2000. Calculation of non-structural carbohydrate content of feeds that contain non-protein nitrogen. Bulletin No. 339. University of Florida, Gainesville.

Hoover, W. H. 1986. Chemical factors involved in ruminal fibre digestion. Journal of Dairy Science 69:2755-2766.

Huhtanen, P.; Jaakkola, S. and Kukkonen, U. 1995. Ruminal plant cell wall digestibility estimated from digestion and passage kinetics utilizing mathematical models. Animal Feed Science and Technology 52:159-173.
Leng, R. A. 1990. Factors affecting the utilization of "poor-quality" forages by ruminants particularly under tropical conditions. Nutrition Research Reviews 3:277-303.

Licitra, G.; Hernandez, T. M. and Van Soest, P. J. 1996. Standardization of procedures for nitrogen fractionation of ruminant feeds. Animal Feed Science and Technology 57:347-358.

Mariz, L. D. S.; Valadares Filho, S. C.; Detmann, E.; Pereira, L. G. R.; Marcondes, M. I.; Santos, S. A.; Villadiego, F. A. C.; Zanetti, D.; Prados, L. F. and Nunes, A. N. 2013. Intake and ruminal digestion determined using omasal and reticular digesta samples in cattle fed diets containing sugar cane in natura or ensiled sugar cane compared with maize silage. Livestock Science 155:71-76.

Melaku, S.; Peters, K. J. and Tegegne, A. 2005. Intake, digestibility and passage rate in Menz sheep fed tef (Eragrostis tef) straw supplement with dried leaves of selected multipurpose trees, their mixtures or wheat bran. Small Ruminant Research 56:139-149.

Menezes, G. C. C.; Valadares Filho, S. C.; Magalhães, F. A.; Valadares, R. F. D.; Mariz, L. D.; Detmann, E.; Pereira, O. G. and Leão, M. I. 2011. Total and partial digestibility, rates of ingestion obtained with rumen evacuation and microbial protein synthesis in bovines fed fresh or ensiled sugar cane and corn silage. Revista Brasileira de Zootecnia 40:1105-1113.

Mertens, D. R. 2002. Gravimetric determination of amylase-treated neutral detergent fiber in feeds with refluxing in beakers or crucibles: collaborative study. Journal of AOAC 85:1217-1240.

Minson, D. J. 1990. Forage in ruminant nutrition. Academic Press, San Diego, CA.

Monteiro, C. C. F.; Melo, A. A. S.; Ferreira, M. A.; Campos, J. M. S.; Souza, J. S. R.; Silva, E. T. S.; Andrade, R. P. X. and Silva, E. C. 2014. Replacement of wheat bran with spineless cactus (Opuntia ficus indica Mill cv. Gigante) and urea in the diets of Holstein $\mathrm{x}$ Gyr heifers. Tropical Animal Health Production 46:1149-1154.

NRC - National Research Council. 2001. Nutrient requirements of the dairy cattle. 7 th ed. Washington, DC.

Storry, J. E. and Sutton, J. D. 1969. The effect of change from lowroughage to high-roughage diets on rumin fermentation, blood composition and milk fat secretion in the cow. British Journal of Nutrition 23:511-521.

Touno, E.; Kaneko, M.; Uozumi, S.; Kawamoto, H. and Deguchi, S. 2014. Evaluation of feeding value of forage soybean silage as a substitute for wheat bran in sheep. Animal Science Journal 85:46-52.

Valadares Filho, S. C.; Moraes, E. H. K; Magalhães, K. A.; Chizzotti, M. L. and Paulino, M. F. 2014. Alternativas para otimização da utilização de ureia para bovinos de corte. In: Anais do 9o Simpósio Internacional de Produção de Gado de Corte - SIMCORTE. Viçosa, Minas Gerais.

Van Soest, P. J. 1982. Nutritional ecology of the ruminant. Corvallis, Oregon.

Vidal, M. F.; Silva, L. A. C.; Sousa Neto, J. and Neiva, J. N. M. 2004. Análise econômica de confinamento de ovinos: o uso da ureia em substituição à cama de frango e a dietas a base de milho e soja. Ciência Rural 34:493-498. 